\title{
SEDIAAN INSEKTISIDA CALOPHYLLUM SOULATTRI: AKTIVITAS INSEKTISIDA DAN RESIDU TERHADAP LARVA CROCIDOLOMIA PAVONANA DAN KEAMANAN PADA TANAMAN
}

\author{
Edy Syahputra ${ }^{1}$, Djoko Prijono ${ }^{2}$, dan Danar Dono ${ }^{3}$
}

\begin{abstract}
Insecticide Preparation of Calophyllum soulattri: Insecticidal and Residual Activity Against Crocidolomia pavonana and Its Savety on Crops. Bioassays were done using leaf-residual method with Crocidolomia pavonana larvae as test insect. The number of dead larvae was recorded daily and was analyzed using probit method. The results showed that methanol extract, and dichloromethane fraction of C. soulattri bark possessed strong lethal effect against C. pavonana larvae with $\mathrm{LC}_{50}$ of $0.15 \%$, and $0.05 \%$, respectively. Dichloromethane fraction of $21 \mathrm{EC}$ and $21 \mathrm{WP}$ sprayed in suspension consentration of $1 \%$ on potted broccoli plant had residual activity around 16\%-26,7\% with range of half-lives of 5.9-7.7 days. Dichloromethane fraction at concentration of $0.2 \%$ and $0.3 \%$ formulated as EC did not cause phytotoxic to broccoli, tomato, chilli, soybean, red bean, onion, cucumber, and maize. Concerning with this potency, further studies are needed to identify insecticidal compounds.
\end{abstract}

Key words: Calophyllum soulattri, insecticidal activity, half-lives, phytotoxicity

\section{PENDAHULUAN}

Informasi tentang jenis-jenis tumbuhan yang memiliki bioaktivitas terhadap serangga telah banyak dilaporkan. Prakash \& Rao (1997) melaporkan bahwa tidak kurang dari 850 spesies tumbuhan yang mempunyai aktivitas insektisida. Selama dekade terakhir, jumlah spesies tumbuhan terus meningkat seiring peningkatan minat dalam pencarian senyawa insektisida dari tumbuhan. Jenis tumbuhan dari suku Clusiaceae merupakan salah satu kelompok tumbuhan yang memiliki aktivitas insektisida (Jacobson, 2003).

Salah satu anggota Clusiaceae yang memiliki sifat insektisida dan berpotensi untuk dikembangkan sebagai sumber insektisida botani adalah Calophyllum soulattri (Syahputra et al., 2004b). Dari hasil pengujian sebelumnya dilaporkan bahwa ekstrak campuran air-aseton-metanol kulit batang $C$. soulattri memiliki aktivitas insektisida yang relatif kuat terhadap ulat $C$. pavonana dengan $\mathrm{LC}_{50} \quad 4,29 \%$. Daun, ranting dan getah kulit batang $C$. soulattri juga dilaporkan memiliki aktivitas insektisida terhadap serangga yang sama. Ekstrak etanol getah kulit batang C. soulattri memiliki aktivitas insektisida yang kuat terhadap larva $C$. pavonana dengan $\mathrm{LC}_{50} \quad 0,04 \%$ (Syahputra et al., 2004a). Selain memiliki aktivitas insektisida, sediaan tersebut juga memiliki aktivitas penghambat makan, penghambat pertumbuhan larva dan dapat menurunkan fekunditas imago C. pavonana.
Pengujian-pengujian awal bahan insektisida tersebut umumnya dilakukan di laboratorium, sebelum digunakan di lapangan untuk pengendalian hama pertanian. Bila bahan tersebut akan digunakan di lapangan, berbagai pertimbangan keamanan harus teruji, di antaranya pertimbangan keamanan terhadap organisme bukan sasaran dan lingkungan. Keamanan terhadap organisme bukan sasaran yang harus diuji di antaranya ialah sifat fitotoksisitas yang dapat ditimbulkan oleh sediaan bahan tersebut. Sedangkan keamanan terhadap lingkungan yang harus diuji dapat berupa aktivitas residunya.

Gejala fitotoksik cenderung terjadi pada tanaman yang diberi perlakuan ekstrak. Ekstrak biasanya terdiri dari banyak gabungan senyawa. Selain senyawa aktif, pada ekstrak kasar juga mengandung komponen-koponen lain. Ekstrak metanol dapat terdiri dari komponen polar hingga komponen nonpolar. Komponen nonpolar yang berwujud minyak atau cairan pekat dapat merusak lilin kutikula daun atau membran sel daun tanaman.

Insektisida yang berasal dari tumbuhan mudah terurai oleh cahaya matahari sehingga umumnya memiliki persistensi yang singkat di lapangan. Data persistensi yang tepat perlu diketahui agar dosis awal yang harus digunakan untuk mencapai tingkat keefektifan pengendalian yang diharapkan selama selang waktu tertentu dapat ditentukan dengan tepat. Bila dosis aplikasi suatu insektisida telah ditentukan, data persistensi dapat digunakan untuk

\footnotetext{
${ }^{1}$ Dosen Fakultas Pertanian, Universitas Tanjungpura, Jalan A. Yani, Pontianak, 78124

${ }^{2}$ Dosen Departemen Proteksi Tanaman, Fakultas Pertanian, Institut Pertanian Bogor, Bogor 16680

${ }^{3}$ Dosen Jurusan Hama dan Penyakit Tumbuhan, Fakultas Pertanian, Universitas Padjadjaran, Bandung
} 
memperkirakan interval aplikasi insektisida tersebut. Selain itu, data persistensi suatu insektisida juga dapat digunakan untuk menentukan selang waktu antara aplikasi terakhir dan panen.

Berdasarkan uraian di atas dapat dikemukakan bahwa selain aktivitas insektisida, ketahanan suatu insektisida yang akan digunakan di lapangan dan sifat fitotoksiknya perlu diketahui terlebih dahulu. Sehubungan dengan hal tersebut, penelitian ini dilakukan untuk mempelajari aktivitas insektisida dan aktivitas residu sediaan kulit batang $C$. soulattri terhadap larva $C$. pavonana, serta sifat fitotoksitas pada sembilan bibit tanaman.

\section{METODE PENELITIAN}

Sumber Ekstrak. Bahan tumbuhan uji yang digunakan ialah kulit batang $C$. soulattri. Bahan tanaman diperoleh dari Kecamatan Teluk Melano, Ketapang, Kalimantan Barat. Kulit batang yang digunakan terlebih dahulu diblender hingga menjadi serbuk dan diayak menggunakan kasa berjalinan 1 $\mathrm{mm}$. Kadar air bahan yang digunakan ialah $13,4 \%$.

Serangga Uji. Serangga uji $C$. pavonana diperbanyak di Laboratorium Fisiologi dan Toksikologi Serangga, Jurusan Hama dan Penyakit Tumbuhan (HPT), Institut Pertanian Bogor (IPB). Serangga dipelihara menurut cara seperti yang diuraikan oleh Prijono (1998).

Ekstraksi dan Fraksinasi. Serbuk kulit batang diekstraksi dengan maserasi selama $3 \times 24$ jam menggunakan metanol. Perbandingan bobot bahan dan pelarut 1:10. Selanjutnya bahan disaring menggunakan corong yang dialasi kertas saring. Hasil penyaringan diuapkan dengan rotary evaporator pada suhu $55-60{ }^{\circ} \mathrm{C}$ dan penghampaan pada tekanan 580$600 \mathrm{mmHg}$ sehingga diperoleh ekstrak metanol. Ekstrak metanol dipartisi dalam campuran heksana dan metanol 95\% dalam labu pemisah. Fase metanol (lapisan pelarut bagian bawah) yang terbentuk dalam labu pemisah ditampung selanjutnya diuapkan pelarutnya. Fraksi metanol yang diperoleh dipartisi lebih lanjut dalam labu pemisah lainnya dalam campuran pelarut etil asetat dan air (1:1). Perbandingan bobot ekstrak dengan campuran pelarut 1:40 (w/v). Fase etil asetat yang diperoleh selanjutnya diuapkan pelarutnya seperti di atas. Fraksi etil asetat difraksinasi lebih lanjut menggunakan teknik kromotografi vakum cair (KVC) (Coll \& Bowden, 1986). Eluen yang digunakan berturut-turut heksana, diklorometanaa, etil asetat, dan metanol dengan fase diam gel silika (Merck; 0,04-0,063 mm). Berdasarkan aktivitas dan rendemennya, dalam percobaan ini digunakan ekstrak metanol dan fraksi diklorometana. Sebagai pembanding pada percobaan fitotoksisitas digunakan fraksi diklorometana-isopropanol (9:1) ranting $A$. odorata.

\section{Metode Pengujian}

Pengaruh Letal Sediaan Kulit Batang $C$. soulattri terhadap Larva $\boldsymbol{C}$. Pavonana. Sediaan yang digunakan dalam pengujian ini ialah ekstrak metanol dan fraksi diklorometana. Pengujian dilakukan dengan metode residu pada daun. Sediaan diuji pada lima taraf konsentrasi yang ditentukan melalui uji pendahuluan. Ekstrak metanol diuji pada konsentrasi $0,175 \% ; 0,18 \% ; 0,2 \% ; 0,23 \%$; dan $0,26 \%$, sedangkan fraksi diklorometana diuji pada konsentrasi $0,02 \%$; $0,03 \% ; 0,04 \% ; 0,06 \%$; dan $0,09 \%$. Untuk mendapatkan larutan sediaan konsentrasi tertentu, ekstrak metanol dilarutkan dengan aseton-metanol 3:1, sedangkan fraksi diklorometana dilarutkan dengan aseton. Sediaan dioleskan secara merata pada setiap permukaan cakram daun brokoli berdiameter 3 $\mathrm{cm}$ menggunakan sonde mikro (microsyringe) sebanyak $25 \mu 1 /$ permukaan. Setelah pelarut menguap, dua potong daun perlakuan diletakkan dalam cawan petri berdiameter $9 \mathrm{~cm}$ yang dialasi tisu. Selanjutnya ke dalam setiap cawan petri dimasukkan 15 ekor larva instar II. Larva kontrol diberi pakan daun yang diolesi pelarut saja sesuai dengan pelarut sediaan yang digunakan. Pemberian pakan daun perlakuan dilakukan selama 48 jam, selanjutnya larva diberi pakan daun tanpa perlakuan hingga mencapai instar IV. Jumlah larva yang mati dicatat. Penentuan nilai $\mathrm{LC}_{50}$ (lethal concentration) dilakukan dengan analisis probit menggunakn program komputer (SAS Institute, 1990).

Aktivitas Residu Sediaan Kulit Batang $C$. soulattri terhadap Larva $C$. pavonana. Sediaan yang digunakan dalam pengujian ini ialah fraksi diklorometana. Sediaan dibuat dalam bentuk formulasi 21 EC (emulsifiabel concentrate) dan 21 WP (wettable powder). Besarnya kandungan fraksi dalam masing-masing formulasi ialah $3 \times \mathrm{LC}_{99}$ berdasarkan hasil uji pengaruh letal di atas. Konsentrasi formulasi yang digunakan adalah $1 \%$ dan volume semprot $430 \mathrm{ml}$ untuk 33 tanaman.

Pembuatan formulasi 21 EC sebanyak $5 \mathrm{ml}$ dilakukan dengan mencampur $21 \%$ fraksi 
diklorometana $(1,05 \mathrm{~g})$, pengemulsi alkilgliserolftalat $7,7 \%(\mathrm{v} / \mathrm{v})$ (Latron $0,5 \mathrm{ml}$ ), alkilarilpoliglikol eter $4 \%$ $(\mathrm{V} / \mathrm{v})$ (Agristick 0,5 ml) dan metanol hingga volume 5 ml. Campuran bahan tersebut dikocok hingga tercampur merata dan siap digunakan. Formulasi fraksi $21 \mathrm{WP}$ dibuat sebanyak $5 \mathrm{~g}$ dengan pembawa kaolin. Pembuatannya dilakukan dengan mencampur fraksi diklorometana $21 \%(1,05 \mathrm{~g})$, pengemulsi alkilgliserolftalat $7,7 \% \quad(\mathrm{v} / \mathrm{v}) \quad$ (Latron $0,5 \quad \mathrm{ml})$, alkilarilpoliglikol eter 3\% ( $\mathrm{v} / \mathrm{v})$ (Agristick 0,5 ml) dan kaolin hingga bobot akhir menjadi 5 g. Campuran bahan-bahan tersebut ditambah $50 \mathrm{ml}$ metanol, dikocok hingga merata kemudian metanolnya diuapkan menggunakan rotary evaporator. Untuk perlakuan yang menggunakan tabir surya $p$ aminobenzoat $(0,2 \%)$ perhitungannya disesuaikan. Kedua formulasi yang diperoleh disimpan dalam lemari es $\left(4{ }^{\circ} \mathrm{C}\right)$ hingga saat digunakan.

Saat akan digunakan, formulasi diencerkan dengan cara mencampur setiap formulasi secara terpisah dengan aquades dalam labu takar $500 \mathrm{ml}$. Dalam percobaan ini digunakan empat perlakuan kontrol di antaranya (1) aquades yang mengandung pengemulsi alkilgliserolftalat $0,077 \%$, perekat alkilarilpoliglikol eter $0,04 \%$, dan metanol $0,14 \%$, (2) aquades yang mengandung pengemulsi alkilgliserolftalat $0,077 \%$, perekat alkilarilpoliglikol eter $0,03 \%$, metanol $0,14 \%$, dan asam $p$-aminobenzoat $0,2 \%$, (3) aquades yang mengandung pengemulsi alkilgliserolftalat $0,077 \%$, perekat alkilarilpoliglikol eter $0,03 \%$, kaolin $0,59 \%$ dan asam $p$-aminobenzoat $0,2 \%$, dan (4) aquades tanpa campuran bahan-bahan di atas.

Sebagai kontrol positif digunakan dua jenis insektisida alami yaitu insektisida bakteri Bacillus thuringiensis, dan spinosad (dari aktinomiset
Saccharopolyspora spinosa), serta insektisida sintetik profenofos (golongan organofosfat) dengan konsentrasi anjuran median yang tertulis pada label kemasan. Secara keseluruhan perlakuan dan kontrol yang diuji pada percobaan ini ditunjukkan pada Tabel 1.

Pengujian dilakukan dengan metode penyemprotan pada tanaman brokoli dalam polybag di ruang terbuka tanpa peneduh. Tanaman brokoli yang digunakan berumur sekitar 7-8 minggu. Saat perlakuan daun tanaman diseragamkan menjadi lima daun per tanaman. Penyemprotan formulasi dan kontrol dilakukan dengan hand sprayer bertekanan. Sebagai perlakuan daun brokoli diambil pada $0,1,2$, $3,5.7,10$, dan 14 hari setelah penyemprotan sebagai pakan. Daun diletakkan dalam wadah plastik $(11 \mathrm{~cm}$ x $9,5 \mathrm{~cm}$ x 4,5 cm), selanjutnya dimasukkan 30 larva instar II C. pavonana. Setelah 48 jam, daun perlakuan diganti dengan daun segar tanpa perlakuan hingga larva mencapai instar IV. Peubah yang diamati adalah mortalitas larva instar II C. pavonana. Data ditransformasi ke $\arcsin \sqrt{ } \mathrm{x}$. Data persentase mortalitas larva setiap perlakuan terhadap waktu dipetakan. Waktu paruh dihitung berdasarkan persamaan regresi hubungan antara waktu dan mortalitas dengan menggunakan rumus (Immaraju et al., 1994):

$$
\mathrm{WP}=(\sqrt{(50+0,5)} \cdot b+a)
$$

WP adalah waktu paruh, $b$ adalah kemiringan regresi, dan $a$ adalah intersep. Sebagai pendukung digunakan data radiasi surya dan curah hujan dari Badan Meteorologi dan Geofisika, Balai Wilayah II, Stasiun Klimatologi Darmaga Bogor.

Tabel 1. Susunan perlakuan pengujian aktivitas residu sediaan kulit batang Calophyllum soulattri

\begin{tabular}{ll}
\hline Perlakuan & Bahan formulasi \\
\hline Kontrol & Aquades \\
& Aquades, pengemulsi, perekat, dan metanol \\
& Aquades, pengemulsi, perekat, metanol, dan $p$-aminobenzoat \\
& Aquades, pengemulsi, perekat, kaolin, dan $p$-aminobenzoat \\
Sediaan fraksi & Fraksi EC, pengemulsi, perekat dan metanol \\
& Fraksi EC, pengemulsi, perekat, metanol dan $p$-aminobenzoat \\
& Fraksi WP, pengemulsi, perekat dan kaolin \\
& Fraksi WP, pengemulsi, perekat, kaolin dan $p$-aminobenzoat \\
Insektisida alami & Bacillus thuringiensis \\
& Spinosad \\
Insektisida sintetik & Profenofos \\
\hline
\end{tabular}


Fitotoksisitas Sediaan Kulit Batang $C$. soulattri pada Bibit Tanaman. Sediaan yang digunakan dalam pengujian ini ialah fraksi diklorometana. Sebagai pembanding digunakan fraksi diklorometanaisopropanol (9:1) ranting A. odorata. Pengujian dilakukan pada 9 bibit tanaman; brokoli, caisin, tomat, cabai, kedelai, kacang merah, jagung, bawang, dan mentimun (umur 4 minggu setelah tanam). Konsentrasi fraksi yang digunakan adalah setara 3 kali $\mathrm{LC}_{99}$ percobaan laboratorium. Sediaan disiapkan dengan aquades yang mengandung metanol dan pengemulsi alkilgliserolftalat. Fraksi berat tertentu dimasukkan ke dalam labu takar $25 \mathrm{ml}$ dan ditambahkan metanol sambil dikocok hingga semua ekstrak terlarut dengan baik. Setelah sediaan larut, pada larutannya diberi pengemulsi dan selanjutnya ditambahkan aquades hingga batas tanda tera. Konsentrasi akhir metanol dan pengemulsi dalam sediaan masing-masing $1 \%$ dan $0,07 \%$. Sebagai kontrol disiapkan aquades yang mengandung metanol dan pengemulsi berturut-turut $1 \%$ dan $0,1 \%$. Sediaan dan kontrol disemprotkan secara terpisah pada bibit tanaman hingga basah menggunakan spreyer bekas botol parfum (kapasitas $25 \mathrm{ml}$ ).

Pengamatan dilakukan pada tiga dan 7 hari setelah penyemprotan. Setiap perlakuan diulang tiga kali. Pengamatan fitotoksisitas dilakukan dengan mengamati bagian helai daun tanaman yang mengalami nekrosis atau pengerutan dengan kertas milimeter. Luas relatif bercak nekrotik dihitung dengan rumus:

Luas relatif bercak nekrotik $=\frac{\text { Luas bercak }}{\text { Luas daun }} \times 100 \%$

\section{HASIL DAN PEMBAHASAN}

Pengaruh Letal terhadap Larva $C$. pavonana. Pengaruh letal yang kuat dari suatu bahan merupakan salah satu syarat dalam pengembangan insektisida botani. Sediaan yang disiapkan dengan pelarut organik dikatakan kuat adalah apabila sediaan tersebut aktif pada konsentrasi di bawah 0,25\%. Hasil analisis probit menunjukkan bahwa perlakuan ekstrak metanol dan fraksi diklorometana kulit batang $C$. soulattri memiliki pengaruh letal yang kuat terhadap $C$. pavonana yang ditunjukkan dengan nilai $\mathrm{LC}_{50}$ di bawah $0,2 \%$ (Tabel 2). Nilai LC $_{50}$ ekstrak metanol dan fraksi diklorometana kulit batang $C$. soulattri terhadap instar II dan instar II-III memiliki besaran yang hampir sama. Fakta tersebut mengindikasikan bahwa senyawa aktif yang terdapat pada kedua sediaan bekerja cepat. Mortalitas larva akibat kedua sediaan tinggi pada awal-awal pengamatan dan tidak ada pertambahan mortalitas yang mencolok pada pengamatan-pengamatan berikutnya. Selain itu, serupanya pola tersebut pada kedua sediaan juga menggambarkan bahwa kemungkinan senyawa aktif yang terkandung pada sediaan tersebut dapat sama. Pernyataan tersebut diperkuat dengan serupanya gejala keracunan larva setelah mengkonsumsi kedua sediaan. Berdasarkan pengamatan visual, larva yang diberi perlakuan sediaan $C$. soulattri menunjukkan tanda-tanda larva mati dengan tubuh yang hitam dan kering tanpa adanya gejala kematian akibat kegagalan pergantian kulit. Gajala kematian larva yang sama mengindikasikan bahwa senyawa aktif yang terdapat pada sediaan kemungkinan dapat sama. Mengingat potensinya, penelitian lanjutan untuk mengembangkan tumbuhan $C$. soulattri sebagai sumber insektisida botani perlu dilakukan.

Aktivitas Residu Fraksi Diklorometana terhadap Larva $C$. pavonana. Penurunan mortalitas larva uji pada residu umur 3, 5, 7, 10, dan 14 hari semakin nyata (Gambar 1). Penurunan mortalitas larva uji pada umur-umur residu tersebut disebabkan rendahnya deposit/residu senyawa aktif yang tertinggal pada

Tabel 2. Parameter hubungan konsentrasi-mortalitas sediaan kulit batang C. soulattri terhadap larva C. pavonana $^{1}$

\begin{tabular}{lrllrllll}
\hline Sediaan & $\mathrm{a}$ & \pm & GB & $\mathrm{b}$ & \pm & GB & LC $_{50}(\mathrm{SK} 95 \%)(\%)$ \\
\hline Ekstrak metanol & 9,07 & \pm & 1,53 & 10,94 & \pm & 2,11 & 0,15 & $(0,13-0,16)$ \\
Fraksi diklorometana & 7,84 & \pm & 1,38 & 6,07 & \pm & 1,04 & 0,05 & $(0,04-0,07)$ \\
\hline
\end{tabular}

${ }^{1}$ Jumlah larva instar II yang diberi perlakuan 375 ekor dan kontrol 75 ekor $a=$ intersep garis regresi, $b=$ kemiringan garis regresi, $\mathrm{GB}=$ galat baku, $\mathrm{SK}=$ selang kepercayaan. 
sediaan yang terdapat pada daun perlakuan setelah disemprotkan. Rendahnya deposit senyawa aktif ini dapat dikarenakan akumulasi dari berbagai faktor.

Setelah waktu tertentu di lingkungan, deposit insektisida mengalami perubahan. Senyawa aktif dapat mengalami degradasi dan perpindahan. Degradasi dapat terjadi oleh mikroorganisme, reaksi kimia, dan fotodegradasi, sedangkan perpindahan dapat dipengaruhi oleh faktor fisik seperti aliran air dan udara. Pada percobaan ini degradasi senyawa aktif oleh mikroflora yang terdapat di permukaan daun brokoli, reaksi kimia senyawa aktif, serta fotodekomposisi oleh sinar ultraviolet dapat terjadi. Curah hujan dapat menyebabkan tercucinya senyawa aktif. Selama pengujian curah hujan tertinggi turun pada hari kedua sebanyak 123,3 mm. Keseluruhan faktor tersebut menyebabkan perubahan sifat kimia atau dapat mengurangi jumlah senyawa aktif yang pada gilirannya dapa menurunkan aktivitas residu. Untuk menyebutkan faktor mana sebagai faktor penentu dalam menurunkan jumlah senyawa aktif tersebut diperlukan penelitian sendiri di luar penelitian ini.

Waktu paruh formulasi EC dan WP fraksi diklorometana berkisar 6,1- 7,7 hari (Tabel 3). Dengan tingginya waktu paruh sediaan formulasi ekstrak tanpa tabir surya tampaknya penambahan tabir surya untuk aplikasi formulasi ekstrak belum diperlukan. Hal senada juga disampaikan oleh Rossalia (2003) yang menggunakan tabir surya $p$ aminobenzoat dalam sediaan fraksi etil asetat Dysoxylum acutangulum. Peningkatkan konsentrasi $p$-aminobenzoat hingga konsentrasi $1 \%$ dalam formulasi EC dan WP yang disemprotkan pada tanaman kedelai tidak memberikan perbedaan aktivitas terhadap larva Spodoptera litura.

Waktu paruh sediaan insektisida botani sangat bervariasi. Selain bergantung pada jenis sediaan bahan tanaman dan tingkat kemurniannya, juga ditentukan dosis awal penyemprotan dan komoditi sasarannya. Senyawa aktif azadirakhtin (92\% azadirakhtin) yang disemprotkan pada tanaman kentang pada konsentrasi $30 \mathrm{mg}$ bahan aktif/l memiliki waktu paruh 14,1 hari terhadap kumbang kentang Colorado (Leptinotarsa decemlineata) (Immaraju et al., 1994). Syahputra et al. (2001) melaporkan bahwa senyawa I dan II dari fraksi aktif kulit batang Dysoxylum acutangulum yang disemprotkan pada tanaman brokoli pada konsentrasi 40 ppm menunjukkan waktu paruh singkat, yakni sebesar 2,9 hari dan 4,6 hari terhadap larva C. pavonana.

Fitotoksisitas Sediaan $C$. soulattri pada Sembilan Bibit Tanaman. Perlakuan fraksi diklorometana kulit batang $C$. soulattri pada konsentrasi $0,2 \%$ dan $0,3 \%$ tidak menyebabkan gejala fitotoksik pada bibit tanaman brokoli, caisin, tomat, cabai, kedelai, kacang undul, bawang, timun, dan jagung umur 4 minggu setelah tanam (MST) (Tabel 4). Sedangkan perlakuan fraksi diklorometan-isopropanol ranting A. odorata menyebabkan gejala fitotoksik pada bibit tanaman brokoli, caisin, kedelai, kacang undul dan jagung. Hal ini menunjukkan bahwa fraksi diklorometana kulit batag $C$. soulattri tidak mengandung senyawa yang bersifat fittoksik, sedangkan fraksi diklorometan-isopropanol ranting A. odorata tidak. Perlakuan fraksi tersebut tidak menunjukkan gejala fitotoksik pada bibit tanaman bawang, timun, tomat, dan cabai. Pada beberapa bibit

Tabel 3. Persamaan regresi dan waktu paruh beberapa bentuk formulasi C. soulattri berdasarkan aktivitas residunya terhadap larva instar II C. pavonana

\begin{tabular}{lcc}
\hline Formulasi $^{\mathrm{a}}$ & Persamaan regresi $^{\mathrm{b}}$ & Waktu paruh (hari) \\
\hline Fraksi EC & $Y=9,65-0,52 X$ & 5,9 \\
Fraksi EC+pAB & $Y=10,41-0,47 X$ & 7,1 \\
Fraksi WP & $Y=9,69-0,49 X$ & 6,1 \\
Fraksi WP+pAB & $Y=10,51-0,39 X$ & 7,7 \\
Bacillus thuringiensis & $Y=10,58-0,22 X$ & 9,0 \\
Spinosad & $Y=10,71-0,28 X$ & 8,8 \\
Profenofos & $Y=11,19-0,46 X$ & 7,9 \\
\hline
\end{tabular}

${ }^{a}$ Konsentrasi cairan semprot $1 \%$. ${ }^{\mathrm{b}}$ Persamaan regresi dihitung setelah data mortalitas ditransformasi ke $\sqrt{ }(y+0,5) . Y=$ mortalitas, $X=$ umur residu 
$\square$ Curah hujan $\quad$ Intensitas penyinaran
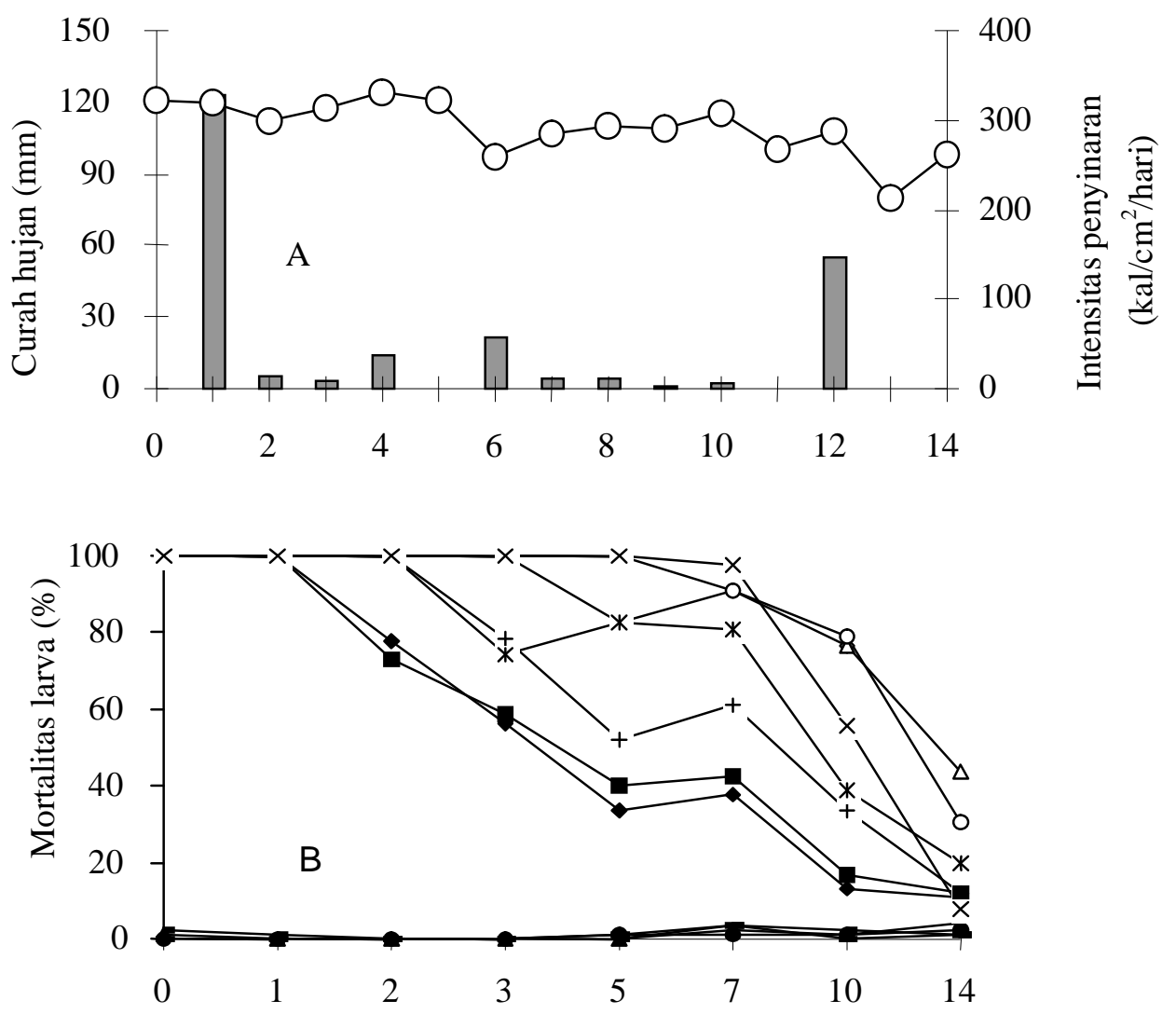

Umur residu (hari)

- Kontrol air

\ Kontrol komponen EC

$\multimap$ Kontrol komponen EC+pAB

-_Kontrol komponen WP+pAB

$\rightarrow$ Fraksi EC
Fraksi EC+pAB

Fraksi WP

Fraksi WP+pAB

Bacillus thuringiensis

Spinosad

Profenofos

Gambar 1. Aktivitas residu formulasi berbagai sediaan kulit batang C. soulattri setelah dipaparkan di ruang terbuka. (A) Curah hujan dan intensitas penyinaran selama pengujian. (B) Mortalitas larva $C$. pavonana instar II. 
tanaman luas gejala fitotoksik semakin bertambah bahkan pada tanaman brokoli dapat menyebabkan kematian.

Bila suatu ekstrak/fraksi tidak menyebabkan gejala fitotoksik atau menyebabkan gejala fitotoksik namun dalam batas yang dapat ditolerir tanaman, sediaan tumbuhan tersebut dapat langsung digunakan setelah disiapkan. Namun bila ekstrak tersebut menunjukkan fitotoksik yang parah, perlu dilakukan pemisahan komponen penyusun ekstrak/fraksi.

Gejala fitotoksik cenderung terjadi pada tanaman yang diberi perlakuan sediaan ekstrak/fraksi insektisida botani, bukan senyawa murni. Azadirakhtin dan rokaglamida yang masing-masing merupakan senyawa murni yang diisolasi dari tumbuhan Meliceae, A. indica dan Aglaia spp, pada konsentrasi yang aktif terhadap hama sasaran tidak menyebabkan fitotoksik pada beberapa tanaman. Pada penelitian lain Loke et al. (1990) melaporkan bahwa penyemprotan ekstrak biji tanaman A. indica pada konsentrasi 0,5 hingga 4,0\% menimbulkan gejala fitotoksik pada tanaman kubis, sawi dan padi berumur 4 minggu. Pada konsentrasi 3\% atau lebih yang diaplikasikan 4 kali dengan interval aplikasi seminggu sekali mengakibatkan kematian seluruh tanaman kubis.

Penjelasan munculnya gejala fitotoksik pada tanaman pada percobaan ini selain dapat dilihat dari sifat sediaan insektisida juga dapat dilihat dari sisi tanaman. Perlakuan sediaan A. odorata yang disemprotkan pada tanaman sukulen seperti tanaman caisin dapat menyebabkan gejala fitotoksik, sedangkan pada tanaman sukulen lainnya seperti bawang perlakuan tersebut tidak menimbulkan gejala fitotoksik. Perlakuan yang sama yang diaplikasikan pada tanaman tomat, kedelai dan jagung yang memiliki trikoma daun yang rapat dapat menyebabkan gejala fitotoksik, sedangkan pada tanaman timun yang sama-sama memiliki trikoma daun yang rapat tidak menunjukkan gejala fitotoksik. Fakta ini mengarahkan pendugaan penyebab fitotoksik kemungkinan bukan disebabkan oleh struktur morfologi daun tanaman melainkan kemungkinan dapat dijelaskan dengan sifat-sifat sel-sel atau ektraseluler jaringan daun yang lebih mendasar yang dikaitkan dengan interaksinya dengan senyawa penyebab fitotoksik. Jenis senyawa penyusun lapisan lilin yang terdapat di permukaan daun tanaman bervariasi. Senyawa-senyawa tersebut meliputi karbohidrat rantai panjang, alkilester, alkohol primer dan asam-asam lemak (Eigenbrode, 1995). Pada permukaan daun tanaman kubis ditemukan lipid dan glukobrassisin (glukosinolat) (Renwick et al., 1992; van Loon et al., 1992).

Sifat fitotoksik dari sediaan A. odorata tampaknya dapat dikaitkan dengan sifat sitotoksik senyawa-senyawa turunan rokaglamida. Hasil percobaan Ohse et al. (1996) menunjukkan bahwa suatu komponen yang diisolasi dari ekstrak $\mathrm{CHCl}_{3} \mathrm{~A}$. odorata bersifat penghambat pertumbuhan sel K-rasNKR dan menghambat sintesis protein. Metilrokaglat ( $1 H$-Cyclopenta[b]benzofuran) bersifat sitotoksik terhadap sel kanker KB (human oral epidermoid carcinoma) (Cui et al., 1997). Bohnenstengel et al.

Tabel 4. Gejala fitotoksisitas pada bibit sembilan jenis tanaman berumur 4 minggu setelah disemprot dengan sediaan $C$. soulattri dan $A$. odorata (pengamatan pada 7 hari setelah penyemprotan)

\begin{tabular}{|c|c|c|c|c|c|c|c|c|c|c|c|c|c|}
\hline \multirow{2}{*}{ Perlakuan } & \multirow{2}{*}{$\begin{array}{c}\text { Kon } \\
\text { sentrasi } \\
(\%)\end{array}$} & \multicolumn{12}{|c|}{$\begin{array}{l}\text { Luas relatif bercak nekrotik }(\%) \text { pada tanaman } \\
\text { yang diberi perlakuan sediaan } \pm \text { simpangan baku }\end{array}$} \\
\hline & & Bkl & & Csn & Tmt & Cbi & $\mathrm{Kdl}$ & & $\begin{array}{c}\mathrm{K} \\
\text { Kndl }\end{array}$ & Bwg & Tmn & & Jgg \\
\hline $\begin{array}{l}\text { C. soulattri } \\
\text { Fraksi }\end{array}$ & 0,20 & 0 & & 0 & 0 & 0 & 0 & & 0 & 0 & 0 & & 0 \\
\hline A. odorata & 0,30 & 0 & & 0 & 0 & 0 & 0 & & 0 & 0 & 0 & & 0 \\
\hline Fraksi ranting & $\begin{array}{l}0,28 \\
0,42\end{array}$ & $\begin{aligned} 8,3 & \pm 5,8 \\
11,7 & \pm 11,5\end{aligned}$ & $\begin{array}{c}6,7 \\
8,3\end{array}$ & $\begin{array}{l} \pm 2, \\
\pm 5,8\end{array}$ & $\begin{array}{l}0 \\
0\end{array}$ & $\begin{array}{l}0 \\
0\end{array}$ & $\begin{array}{l}2,5 \pm \\
5\end{array}$ & 3,5 & $\begin{array}{l}0 \\
0\end{array}$ & $\begin{array}{l}0 \\
0\end{array}$ & $\begin{array}{l}0 \\
0\end{array}$ & $\begin{array}{l}6,7 \\
10\end{array}$ & $\begin{array}{l} \pm 2,9 \\
\pm 0\end{array}$ \\
\hline
\end{tabular}

Keterangan $: \mathrm{Bkl}=$ Brokoli; $\mathrm{Csn}=$ Caisin; $\mathrm{Tmt}=$ Tomat; $\mathrm{Cbi}=$ Cabai; $\mathrm{Kdl}=$ Kedelai; $\mathrm{K}$ Undl $=$ Kacang Undul; Bwg = bawang; Tmn = Timun; Jgg = Jagung 
(1999) melaporkan didesmetilrokaglamida merupakan senyawa yang paling aktif menghambat proliferasi sel kanker MONO-MAC-6 (human acute monocytic leukimia cell line) dan MEL-JUSO (human melanoma cell line).

Mengingat potensi sifat insektisidanya, teknologi untuk mengurangi atau meniadakan pengaruh fitotoksik ekstrak ranting $A$. odorata perlu dikembangkan. Salah satu di antaranya adalah pemanfaatan sifat antagonisme dari suatu pencampuran dua jenis senyawa yang berbeda. Pencampuran ini diharapkan dapat mengubah sifat toksik senyawa campuran tanpa mengakibatkan perubahan/penurunan sifat insektisidanya (antagonisme) atau bahkan diharapkan campuran tersebut dapat menunjukkan sifat sinergisme.

Sifat-sifat senyawa insektisida botani selain efektif terhadap hama sasaran, rendemen yang tinggi, aman terhadap organisme non-target, spektrum bioaktivitas, senyawa insektisida botani yang nonfitotoksik merupakan salah satu pertimbangan yang penting yang dapat digunakan untuk mengembangkan suatu sediaan menjadi insektisida botani baru. Dengan rendahnya gejala fitotoksistas yang ditimbulkan oleh ekstrak/fraksi kulit batang $C$. soulattri tersebut, sangat dimungkinkan dilakukan penelitian-penelitian lainnya yang berkenaan dengan pengembangannya sebagai insektisida botani.

\section{SIMPULAN}

Sediaan kulit batang $C$. soulattri dalam bentuk ekstrak metanol dan fraksi diklorometana memiliki aktivitas insektisida yang kuat terhadap larva C. pavonana dengan konsentrasi letal median $\left(\mathrm{LC}_{50}\right)$ masing-masing $0,15 \%$, dan $0,06 \%$. Pada residu umur 14 hari, formulasi EC dan WP fraksi diklorometana memiliki aktivitas residu berkisar 16\%-26,7\% dengan kisaran waktu paruh 6,7 - 8,2 hari. Fraksi tersebut pada konsentrasi $0,2 \%$ dan $0,3 \%$ tidak menunjukkan gejala fitotoksik pada bibit tanaman brokoli, caisin, tomat, cabai, kedelai, kacang undul, bawang, timun, dan jagung. Dengan memperhatikan potensi aktivitas tersebut maka diperlukan penelitian lanjutan untuk mengidentifikasi senyawa aktif.

\section{SANWACANA}

Penelitian ini dibiayai oleh Penelitian Hibah Bersaing X (2002) kepada Edy Syahputra. Ucapan terima kasih disampikan kepada Bapak Agus Sudrajat atas bantuan pemeliharaan tanaman uji.

\section{DAFTAR PUSTAKA}

Bohnenstengel, F.I., K.G. Steube, C. Meyer, B.W. Nugroho, P.D. Hung, L.C. Kiet \& P. Procks. 1999. Structure activity relationships of antiproliferative rocakglamide derivatives from Aglaia ssp. (Meliaceae). J. of Biosciences (Z. Naturforsch). 54C: 55.

Coll, J.C. \& B.F. Bowden. 1986. The application of vacuum liquid chromatography to the separation of terpene mixtures. J. Nat. Prod. 49(5)934-936.

Eigenbrode, S.D. \& K.E. Espelie. 1995. Effects of epicuticular lipids on insect herbivores. Annu. Rev. Entomol. 40:171-194.

Immaraju, J., S. Wells, W. Ruggero, R. Nelson \& B. Selby. 1994. Relative residual activities of azadirakhtin, dyhidroazadirakhtin and tetrahydroazadirachtin, pp 53-58. Proc. Brighton Crop. Protection Conference.

Jacobson, M. 2003. Insecticides, insect repellents, and attractants from arid/semiarid-land plants, pp 138-146. In: Plants: The Potentials for Extracting Protein, Medicines, and Other Useful Chemicals. Workshop Proceedings. http://www.wws.princeton.edu/cgibin/byteserv.prl/ ota/disk3/1983/8315/8315 11/pdf. [25 Oktober 2003].

Loke, W.H., C.K. Heng, N. Basirun \& A. Rejab. 1990. Non-target effects of neem (Azadirachta indica A. Juss) on Apanatales plutellae Kurdj., cabbage, sawi and padi, pp 108-110. Proceedings $3^{\text {rd }}$ International Conference on Plant Protection in the Tropics. March 20-23, 1990. Malaysian Plant Protection Society. Genting highland, Pahang, Malaysia.

Ohse, T., S. Ohba, T. Yamamoto, T. Koyano \& K. Umezawa. 1996. Cyclopentabenzofuran lignan protein synthesis inhibitors from Aglaia odorata. J. Nat. Prod. 59: 650-652. 
Prakash, A. \& J. Rao. 1997. Botanical Pesticides in Agriculture. Lewis Publishers, Boca Raton.

Prijono, D. 1998. Insecticidal activity of Meliaceous seed extracts against Crocidolomia binotalis Zeller (Lepidoptera: Pyralidae). Bul. H.P.T. 10:1-7.

Renwick, J.A.A., C.D. Radke, K. Sachdev-Gupta \& E. Stadler. 1992. Leaf surface chemicals stimulating oviposition by Pieris rapae on cabbage. Chemoecology 3: 33-38.

Rossalia, D. 2003. Formulasi insektisida botani dari Dysoxylum acutangulum Miq. (Meliaceae) (Tesis). Program Pascasarjana, Institut Pertanian Bogor, Bogor.

S.A.S. Institute. 1990. SAS/STAT User's Guide, Version 6. Fourth Edition, Volume 2. Raleigh: SAS Institute Inc.

Syahputra, E., S. Manuwoto, L.K. Darusman, Dadang \& D. Prijono. 2004a. Aktivitas insektisida bagian tumbuhan Calophyllum soulattri Burm. f. (Clusiaceae) terhadap larva Lepidoptera. J.H.P.T. Trop 4(1):23-31.
Syahputra, E., D. Prijono, S. Manuwoto, L.K. Darusman \& Dadang. 2004b. Aktivitas insektisida ekstrak kulit batang empat famili tumbuhan terhadap ulat krop kubis Crocidolomia pavonana (F.) J. Perlind. Tan. Indon. 10(1):13-22.

Syahputra, E., D. Prijono \& Simanjuntak. 2001. Aktivitas residu fraksi aktif kulit batang Dysoxylum acutangulum Miq. (Meliaceae) terhadap ulat kubis Crocidolomia binotalis Zeller (Lepidoptera: Pyralidae), pp 83-92. In: Prosiding Seminar Nasional III Pengelolaan Serangga yang Bijaksana Menuju Optimasi Produksi, Bogor, 6 November 2001. Perhimpunan Entomologi Indonesia Cabang Bogor, Bogor.

van Loon, J.J.A., A. Blaakmeer, F.C. Griepink, T.A. van Beek, L.M. Schoonhoven \& A.E. de Groot. 1992. Leaf surface compound from Brassica oleracea (Cruciferae) induces ovoposition by Pieris brassicae (Lepidoptera: Pieridae). Chemoecology 3: 39-44. 